\title{
Excomuniones y procesos judiciales contra seres irracionales en la España del siglo XVII
}

\author{
JuAn Cosme SANZ LARROCA*
Excommunications and legal prosecutions against irrational creatures in the Spain of the XVII century

\begin{abstract}
RESUMEN
Una de las respuestas religiosas ante las plagas del campo en la España del siglo $X V I I$ fueron las excomuniones y procesos judiciales contra animales. Estos métodos, infrecuentes durante la Edad Moderna a falta de estudios más concretos, fueron duramente criticados por la religiosidad oficial. Al margen de las opiniones que los autores del siglo XVII español tuvieron sobre el tema, se analizan en este trabajo los casos más conocidos durante la Alta Edad Moderna, sobresaliendo entre todos ellos el famoso proceso de Párraces.
\end{abstract}

PALABRAS CLAVE: Excomuniones / procesos judiciales / animales / España / siglos XVI y XVII

\begin{abstract}
One of the religious responses to the rural plagues in the Spain of the XVII century were excommunications and legal prosecutions against animals. Unless more ample studies could state the contrary, this methods were very unusual throughout the Modern Era, and received hard criticism from the official church. Taking apart the opinions of the Spanish $X V I I$ century authors regarding this subject, the most known cases of the Early modern period are analyzed in this paper, the most remarkable among them all is the famous Párraces' Trial.
\end{abstract}

KEYWORDS:

Excommunications / legal prosecutions / animals / Spain / XVI and XVII centuries.

Recibido: 11-02-2010

Aceptado: 31-05-2010

* Universidad Nacional de Educación a Distancia. Dpto. de historia moderna, Senda del Rey, no 7, madrid 28040. sanzlja@ munimadrid.es 


\section{ANTECEDENTES}

Durante los siglos XIII-XV, las órdenes mendicantes van a ejercer en toda Europa occidental un proceso evangelizador a gran escala, que va a hacer cambiar el viejo sustrato cultural de tradiciones folklóricas antiguas. Esta contaminación provoca la aparición de un conjunto de creencias diferentes a las que propugna la Iglesia, pero que poseen una estructura coherente que intenta responder a un mundo exterior considerado hostil. Dos formas de interpretar el mundo aparecen definidas sobre el escenario cultural de la Baja Edad Media, y van a pasar casi intactas a la Edad Moderna: la religiosidad oficial y la folklórica, con lógicas, contenidos y objetivos diferentes ${ }^{1}$.

Así, en el siglo XVII, nos encontramos, por una parte, con una religiosidad institucional, de fuerte elaboración intelectual, orientada esencialmente hacia la salvación del hombre, fundamentada en un Dios premiador y castigador, y en la que el sacerdote es el necesario intermediario entre ése y el hombre.

Junta a ésta, hallamos un sentido religioso popular, en origen poco o nada elaborado, centrado en dar respuestas a las necesidades más inmediatas de la existencia, y deseando un contacto directo con Dios, en tanto que vértice de una serie de poderes extraordinarios, a los que se puede recurrir en toda situación de peligro².

Esta religiosidad popular, en la que se halla encuadrada gran parte de la sociedad $^{3}$, se encuentra enraizada en el universo animista tradicional y tiende al politeísmo, aunque manteniendo ropajes del catolicismo tridentino. Por ello, presenta unos contenidos que están en la frontera entre lo sacro y lo profano, siendo lo que denominamos una «religiosidad fronteriza» ${ }^{4}$. Ello hace que, para la cultura oficial, ésta contenga gran número de supersticiones, en cuanto que son manifesta-

1 GELABERTÓ, M., La palabra del predicador, Tesis Doctoral (ya publicada), Universidad Autónoma de Barcelona. 2003, pp. 5-7.

2 DOMíNGUEZ ORTIZ, A., «El Antiguo Régimen: los Reyes Católicos y los Austrias», ARTOLA, M. (dir.), Historia de España, tomo 3, Madrid, Alianza Editorial, 1988, p. 411; LÓPEZ, R. J., «Las rogativas públicas en Oviedo (1550-1840)», Revista de Dialectología y Tradiciones Populares, XLIV (1989), pp. 187-200 (187-188).

3 José Luis Sanchez Lora manifiesta su oposición al término «religiosidad popular» precisamente por ser compartido por todos los estamentos sociales, culturales y religiosos, y porque lejos de tratarse de manifestaciones «populares», fueron compartidas y enseñadas por la jerarquía eclesiástica, SÁNCHEZ LORA, J. L., «Claves mágicas de la religiosidad barroca», en ÁLVAREZ SANTALÓ, L. C., BUXÓ, Ma J., y RODRÍGUEZ BECERRA (Coords.), La religiosidad popular, Barcelona y Sevilla, Anthropos y Fundación Machado, 1989, vol II, p. 125.

4 «El hombre de la llamada Edad Moderna, descendiente directo y en tantas cosas sin romper una línea de continuidad del medieval, vivía inmerso en un mundo difuso, medio divino, en el que la realidad, la fantasía, lo religioso y lo supersticioso eran de difícil delimitación y de toda esta amalgama de creencias gran número de eclesiásticos no estaban exentos. Así, mientras que la Iglesia como institución intentó por todos los medios combatir cuanto oliese a superstición, sin lograrlo, pues la lucha continúa hasta nuestros días, el campesino, el hombre de la calle, se mantenía aferrado a sus creencias ancestrales, transmitidas por sus mayores» (BLÁZQUEZ MIGUEL, J., Eros y Tanatos. Brujería, hechicería y superstición en España, Toledo, Editorial Arcano, Serie Striga 1, 1989, p. 135). 
ciones de carácter sagrado fuera del control eclesiástico y con supervivencias paganas, las cuales, en su inmensa mayoría, eran creencias y prácticas con las que el pueblo lo único que pretendía era intentar hacer frente a un mundo hostil y sin control, lleno de muertes, enfermedades, tempestades o plagas 5 .

Sin embargo, a pesar de todos los esfuerzos llevados a cabo por las autoridades religiosas del país, la frontera entre ortodoxia y heterodoxia era una línea muy delgada, hasta tal punto que, muchas veces, incluso los clérigos tenían dificultades para quedarse en el territorio estricto de lo ortodoxo. Así, a veces, se producían dudas o vacilaciones que llevaban a los eclesiásticos a evacuar consultas a la superioridad. Por ejemplo, Martí Gelabertó nos refiere cómo en 1618 un canónigo de la Iglesia de Barbastro hubo de solicitar a la Sagrada Congregación de Ritos de Roma dictamen sobre si mojar en el agua cualquier tipo de reliquia, en tiempos de tempestad, era lícito o no. La contestación fue negativa ${ }^{6}$.

En el caso de las plagas del campo, va a ocurrir algo parecido. Así, incluso en ceremonias tan formalmente aceptadas como misas, procesiones, bendiciones 0 conjuros, siempre debían mantenerse los requisitos básicos que pedían las autoridades, para no ser consideradas al margen de la norma. Sin embargo, existía otra clase de prácticas ejercidas en determinadas situaciones, que en la inmensa mayoría de teólogos y moralistas suscitaban más dudas que el resto en cuanto a su ortodoxia, y que generaron un importante debate en cuanto a la idoneidad de su utilización. Se trataba especialmente de las excomuniones y de los procesos judiciales a irracionales dañinos, perfectamente definidos por Benito R. Noydens:

«Porque ay algunos que suelen descomulgarlas [a las plagas], y formar contra ellas cabeça de processo, con sus procuradores de una, y otra parte para alegar cada uno su derecho, y después de muchas demandas, y respuestas, fulminan sentencia de descomunión mayor, para que las langostas se aparten de los terminos del lugar, como si tuvieran libre aluedrio, y fuesen capaces de las censuras, que ordena la Iglesia, para reducir á los hombres contumaces á su obediencia» .

\footnotetext{
5 Para Jean Delumeau, las poblaciones de la época moderna se consideraban cristianas y no tenían el sentimiento de hallarse vinculadas a una religiosidad condenada por la Iglesia. Y debieron quedarse muy sorprendidas por la intensiva aculturación emprendida en Europa por los misioneros de las dos Reformas, que veían paganismo por todas partes: «Este era, desde hacía tiempo, un espejo roto, un universo estallado. Subsistió seguramente en nombres deformados de divinidades y bajo la forma de mentalidades y comportamientos mágicos, pero sin panteón, por poco organizado que estuviera, ni sacerdotes (o sacerdotisas), ni cuerpo de doctrina. Quizá era vivido, pero no era pensado ni querido», DELUMEAU, J., El miedo en Occidente (siglos XIV-XVIII). Una ciudad sitiada, Madrid, Taurus, 1989, p. 572.

6 VICENS, G., Miscelánea político-eclesiástica, Ms. 1010 Biblioteca Universitaria de Barcelona, pp. 121-122, cit. en GELABERTÓ, M., «Tempestades y conjuros de las fuerzas naturales. Aspectos mágico-religiosos de la cultura de la Alta Edad Moderna», en Manuscrits, 9 (enero 1991), pp. $325-344$ (336).

7 NOYDENS, B. R., Práctica de exorcistas y ministros de la Iglesia. En que con miucha erudicion, y singular claridad, se trata de la instrucción de los Exorcismos, para lançar, y auyentar los demonios, y curar especialmente todo genero de maleficios, y hechizos, Barcelona, por loseph Llopis, en la plaça del An-

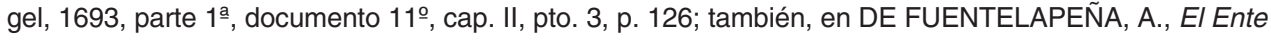
dilucidado. Discurso unico novissimo que muestra ay en la naturaleza animales irracionales invisibles, $y$ quales sean, Madrid, en la imprenta real, 1676, secc. 3aㅗ , subsecc. 5, instancia 11, ํㅡ 697, p. 185.
} 
A pesar de que, estrictamente, se trata de dos términos diferentes, vamos a ocuparnos de forma conjunta de las excomuniones y de los procesos judiciales por dos motivos, que demuestran la interacción de ambos. En primer lugar, varios de los autores del siglo XVII consultados aluden de manera indistinta en su crítica a ambas prácticas. Y en segundo lugar, estaba la concreción de este tipo de actuaciones. Así, aunque no toda excomunión a la que se referían los tratadistas analizados requería un proceso judicial, sin embargo, cualquier proceso conllevaba la amenaza primero, y más tarde la ejecución de una excomunión si el animal dañino no obedecía la sentencia.

Para empezar, hay que señalar que en la Edad Media confluyen dos corrientes de pensamiento respecto a los animales. Por una parte, de forma claramente mayoritaria, hallamos la que opone con la mayor rotundidad posible al hombre, creado a imagen y semejanza de Dios, a la criatura animal, inferior, sumisa e imperfecta, si no impura. Por otro lado, encontramos la idea de una comunidad de seres vivos, influida determinantemente por Aristóteles y San Pablo, en particular a través de un fragmento de la Epístola de este último a los Romanos: «La creación entera espera anhelante ser liberada de la servidumbre de la corrupción, para participar en la libertad de la gloria de los hijos de Dios»8.

Esta frase hace reflexionar a partir de entonces a muchos teólogos, que se preguntan si Cristo vino a salvar a todas las criaturas, si los animales son también hijos de Dios y, en esta línea, si hay que tratarlos como a seres con responsabilidad moral. Esta última pregunta abre la cuestión de los juicios a animales desde mediados del siglo XIII, influida también por el repliegue, desde ese instante, de la cristiandad occidental sobre sí misma y la conversión de la Iglesia en un enorme tribunal (creación del tribunal eclesiástico, de la Inquisición y del procedimiento inquisitorial) ${ }^{9}$.

Aunque el primero que habló sobre la posibilidad de enjuiciar a los animales parece que fue el filósofo presocrático Demócrito, y más tarde Platón consideró que debía sacrificarse y echar fuera de los términos de un territorio al irracional que matase a alguien ${ }^{10}$, es en la Edad Media cuando, de alguna manera, se concibe la idea general de la responsabilidad penal de los animales. Frente a esta tradición, Alfonso XI primero, en 1348, y los Reyes Católicos después, en 1480, promulgaron en Castilla sendas leyes para acabar con esa responsabilidad de seres irracionales o inanimados ${ }^{11}$.

8 PASTOREAU, M., Una historia simbólica de la Edad Media occidental, Buenos Aires, Katz Editores, 2006, pp. 28-30.

9 Idem, pp. 30-31.

10 DE LORA, P., Justicia para los animales. La ética más allá de la humanidad, Madrid, Alianza Editorial, 2003, pp. 46-47.

11 TOMÁS Y VALIENTE, F., El Derecho Penal de la Monarquía absoluta (siglos XVI, XVII y XVIII), Madrid, Tecnos, 1969, pp. 296-297. 
Paralelamente a estas ideas, la teología medieval, propiamente hablando, no permitía excomulgar a las bestias, sino tan sólo anatematizarlas, en la medida en que no formaban parte de la comunión de la Iglesia. Esta formulación seguía la doctrina de Santo Tomás, lo que no fue óbice, como veremos, para que en los siglos XVI y XVII se siguieran efectuando excomuniones a irracionales.

Por otra parte, el Medievo también consignó el orden de la naturaleza, según el cual cada elemento tenía un lugar asignado en ella y una misión que cumplir, y si no se realizaba debidamente, merecía un castigo, y para mayor justicia, éste se le podía imponer mediante un proceso penal en el que resultara comprobada la culpabilidad del animal o del ser inanimado delincuente ${ }^{12}$.

Otro elemento a tener en cuenta en la existencia de los procesos judiciales fue el animismo, idea que inundó toda la Edad Moderna y, según la cual, todas las cosas cuentan con un alma, están por tanto animadas por espíritus poderosos, pero invisibles que se esconden en ellas o están detrás de ellas ${ }^{13}$.

Además, en los siglos XV al XVII van a aparecer algunos jurisconsultos en Europa que se interrogaron sobre la legitimidad y la eficacia de los juicios a animales, y que realizaron varias recopilaciones, a veces incluso verdaderos tratados, entre los que sobresale la obra de Barthélemy de Chasseneuz (1480$1541)^{14}$. En esas obras aparecen todas las cuestiones relativas a la responsabilidad penal de los irracionales, y los medios que podían aplicarse contra ellos, entre los que destacaban los conjuros, los anatemas, las maldiciones y las excomuniones.

En cuanto a los casos de procesos judiciales contra plagas ${ }^{15}$, el testimonio más antiguo en Francia (aunque dudoso) se produce en la diócesis de Laon, en 1120, contra ratones y orugas, a los que se declara «malditos y excomulgados», y al año siguiente se da otro contra moscas. En 1516, el obispo de Troyes ordena a los hurebets (especie de saltamontes) que han invadido las viñas que abandonen su diócesis bajo la pena de excomunión. Lo mismo ocurrirá en 1543 en la diócesis de Valencia contra las babosas, y en 1585 en la diócesis de Grenoble contra las oru-

12 Idem, p. 298.

13 Idem, p. 298, nota 11.

14 El tratado principal de este magistrado borgoñón, más conocido como Chassenée, fue Consilia, Lyon, 1531, 1ㄹ parte, «De excommunicatione animalium et insectorum». Otros autores fueron PAPE, G., Decisiones, Grenoble, 1490; DURET, J., Traicté des peines et amendes tant pour les matières criminelles que civiles, Lyon, 1573, pp. 436-443 ; y AYRAULT, P., LNordre, formalité et instruction judiciare, 4ª edición, París, 1610, pp. 602 y ss. Todo, en PASTOREAU, M., op. cit., pp. 37-38 y n. 31.

15 Michel Pastoreau distingue tres tipos de juicios: a) contra animales domésticos (cerdos, bovinos, caballos...), considerados individualmente, y que mataron o hirieron de gravedad a personas, a los que se juzga criminalmente; b) contra animales colectivamente, ya sean mamíferos salvajes grandes (jabalíes, lobos...), a los que se persigue mediante batidas, o animales de pequeño tamaño (roedores, insectos...), que requieren la intervención de la Iglesia; c) animales implicados en crímenes de bestialismo, PASTOREAU, M., op. cit., pp. 40-44. 
gas. Muy numerosos son también los juicios contra plagas del campo en las regiones alpinas. El último caso encontrado data de 1735 en Besançon ${ }^{16}$.

Centrándonos ya en España, parece que no se encuentran huellas de procesos a irracionales hasta el siglo XIV según Feijóo ${ }^{17}$. Sin embargo, los casos mejor conocidos empiezan en el siglo XVI. Así, en 1532, nos encontramos con un proceso contado por Gil González Dávila en su Teatro Eclesiástico de la Santa Iglesia de Oviedo ${ }^{18}$. Ese año, ante una gran plaga de ratones en la comarca de la Liébana, los labradores de la zona deciden presentarse ante el vicario general, Diego Pérez de Villaviciosa, solicitándole alguna medida efectiva contra la calamidad. Ante ello, Don Diego dispone un juicio de faltas contra los roedores, dotando a éstos de abogado y procurador, mientras los rústicos se presentan como querellantes.

Ambas partes presentan alegaciones, demandas, pruebas, etc., haciéndose una vista pública final, en la que el provisor de la causa pronuncia sentencia ejecutoria contra los ratones, para que, en el plazo de tres días, dejen la tierra de labor, so pena de considerarlos rebeldes y en desacato. Además, para el cumplimiento de la sentencia, el abogado pide que se coloquen maderas y troncos sobre los ríos o arroyos, con el fin de facilitarles la huida, cosa que admitió el provisor. Según el autor, los ratones, finalmente, hicieron caso.

También de la primera parte del siglo XVI —ignoramos la fecha exacta, pero la alusión en un determinado momento al término «Emperador» nos sitúa la acción durante la época de Carlos I- conocemos un pleito realizado contra la langosta en Valladolid. Esta ciudad, así como las localidades cercanas de Puente de Duero (actual Puente Duero-Esparragal) y Viana (actual Viana de Cega), que entonces pertenecían a la tierra y jurisdicción de la primera, llevaban azotadas un mes por una terrible plaga, cuando las autoridades eclesiásticas decidieron formar un pro-

16 Idem, pp. 39-40.

17 DOMíNGUEZ ORTIZ, A., «Aspectos de la España de Feijóo», en Hechos y figuras del XVIII español, Madrid, Siglo XXI de España Editores, pp. 177-214 (184). Entre los diferentes testimonios que han llegado hasta nosotros, estarían las siguientes: cuatro sentencias de excomunión dictadas por vicarios generales y provisores en Francia, contra plagas; golondrinas excomulgadas por el obispo de Córdoba, por hacer alboroto en una iglesia, tras un proceso judicial; anguilas excomulgadas, ya que hacían daño a quienes las comían; langostas a las que el obispo El Tostado, de Ávila, formó proceso, sentenciándose a recogerse todas en una cueva; moscas que alborotaban en una iglesia (NAVARRO, G., Tribunal de Superstición Ladina, Explorador del saber, astucia, y poder del Demonio; en que se condena lo que suele correr por bueno en Hechizos, Agüeros, Ensalmos, vanos Saludadores, Maleficios, Conjuros, Arte notoria, Cavalista, y Paulina, y semejantes acciones vulgares, En Huesca, por Pedro Blusón, Impressor de la Vniversidad, Año 1631, disp. XXXII; DE QUIÑONES, J., Tratado de las langostas muy vtil y necessario, En que se tratan cosas de prouecho y curiosidad para todos los que professan letras diuinas y humanas, y las mayores ciencias, en Madrid, por Luis Sánchez, impressor del Rey nuestro Señor. Año MDCXX, cap. III, fols. 44v-46r; y ZARCO CUEVAS, J., Pleito que se puso en la Abadía de Párraces para el exterminio de la langosta. Año de 1650, Madrid, Tipografía de Archivos, 1932, pp. 21-22).

18 Madrid, 1635, p.; también, ver NAVARRO, G., op. cit., disp. XXXII, fol. 96r y CASAS GASPAR, E., Ritos agrarios. Folklore campesino español, Madrid, Editorial Escelicer SL, 1950, pp. 72-73. 
ceso en una abadía de la ciudad ${ }^{19}$. Del pleito, tan sólo se conserva, aparte de los datos personales de algunos de los que intervinieron, la demanda del fiscal y la defensa del abogado de la langosta.

El fiscal solicitará del juez encargado del caso la obligación de que las langostas abandonen el lugar, con apercibimiento de excomulgarlas, debido a los efectos negativos que conllevaba su presencia. Entre ellos, destacaba la destrucción de pan, vino y hierbas, lo que creaba enormes dificultades para el mantenimiento de las gentes, el pago de diezmos y primicias, las limosnas a los pobres y la celebración de sacrificios (misas) a Dios.

Sin embargo, la parte más interesante del texto corresponde a los fundamentos que utiliza el abogado de la langosta. Sucintamente, pueden dividirse en dos grandes apartados:

1) Falta de jurisdicción del juez encargado del proceso

En primer lugar, la langosta no es súbdita de ninguna jurisdicción temporal o espiritual, al no ser humana. En segundo, si alguna jurisdicción pudiera corresponderle, ésta no sería la espiritual, porque ni es racional ni es cristiana. Pero si, por alguna causa estuviera bajo jurisdicción espiritual, no sería ésta la del juez de la abadía vallisoletana, sino la del tribunal de Dios, ya que la langosta es enviada directamente por Él contra los hombres por sus pecados. Y en tercer lugar, si no estuviera bajo jurisdicción espiritual, estaría bajo la temporal, siendo la justicia real la que corresponde, al hallarse la plaga en tierra de realengo.

2) Elementos erróneos en la demanda del fiscal

El primero era que la demanda no va contra un ser racional, por lo que es supersticiosa y contraria a la doctrina católica y a la opinión de gran número de autores. El segundo, si en lugares tan civilizados como Valladolid, se produce un proceso como éste, es lógico pensar que en lugares remotos y más atrasados (Galicia, Asturias) se hayan realizado este tipo de actos, por lo que es fundamental castigar rigurosamente a los promotores del proceso, para evitar su repetición en el futuro. El tercer elemento consistía en que la langosta ha llegado a Valladolid por la voluntad de Dios, debido a los pecados de los hombres. Frente a este hecho, no cabe resistirse, y sí aceptarlo, y suplicarle piedad y el cese de su ira. Por ello, las autoridades eclesiásticas deben amonestar a sus fieles, exhortándoles a que reconozcan la voluntad divina y los pecados realizados, lleven a cabo oraciones, ayunos y vigilias y tengan el propósito de no ofender más a Dios. Además, se pueden utilizar exorcismos.

Finalmente, el abogado defensor establece tres conclusiones al respecto. Primera, el juez de la causa debe declararse incompetente en la misma, trasladándola a un juez seglar o al tribunal de Dios. Segunda, la superstición guía, sin

19 Zarco Cuevas lo sitúa a fines del siglo XV-comienzos del XVI, ZARCO CUEVAS, J., op. cit., p. 7. 
duda, el uso de la excomunión y proceso judicial. Y tercera, hay que estar en absoluta disconformidad con la continuidad del proceso 20 .

\section{REQUISITOS Y CRÍTICAS}

Antes de entrar a ver las diferentes opiniones que durante el siglo XVII se tuvieron sobre la cuestión, merece la pena decir unas palabras sobre el término «excomunión». Este se encuentra perfectamente definido por Francisco de Toledo en su Instrucción de sacerdotes como «vna censura Eclesiástica, con la qual el Christiano es priuado de los bienes comunes de los fieles», en los que se incluye la comunicación exterior con el resto de los devotos, la participación en los sacramentos y las oraciones y los sufragios de la Iglesia.

Toledo señala igualmente que existen dos tipos de censuras, como son la mayor, que priva a los fieles de los bienes citados, y la menor, que sólo priva de recibir los sacramentos. Además, toda excomunión debía contar con dos requisitos fundamentales para que se pudiera iniciar el proceso: la existencia de pecado mortal y la contumacia por parte del sujeto ${ }^{21}$.

A partir de esta censura eclesiástica, los autores polemizaron en cuanto a su aplicación sobre seres irracionales —como las plagas - e inanimados — como los fenómenos meteorológicos-. En este sentido, la inmensa mayoría va a reprobar tajantemente las excomuniones y los procesos judiciales, siguiendo la estela dejada en el siglo anterior por autores como Domingo de Soto, Martín de Azpilcueta, Francisco Suárez, Tomás Sánchez, Pedro Jerónimo Cenedo, Rafael de la Torre, Pedro de Aragón o Miguel Bartolomé Salón²2. El propio Concilio de Trento es-

20 FERNÁNDEZ DURO, C., «Pleito contra la langosta», Boletín de la Real Academia de la Historia, tomo XXXVIII, cuaderno IV (abril 1901), pp. 322-325; también, en Real Academia de la Historia, Colección Salazar, Ms. 140, fols. 228r-230v.ç

21 DE TOLEDO, F., Instrucción de sacerdotes y suma de casos de conciencia, En Valladolid, por la Vda. de Francisco de Cordoua, 1627, lib. I, caps. IV-VII, fols. 5v-8v.

22 Los autores y obras son los siguientes: DE SOTO, D. (O.P.), De iustitia et iure..., Salamanca: excudebat loannes Baptista à Terranoua: expensis Benedicti Boyrij, 1568; DE AZPILCUETA, M., Manual de Confessores, cap. 17, no 13; SUÁREZ, Francisco (S.I.): Disputationum de censuris en communi excommunicatione, suspensione et interdicto itemque de irregularitate..., Lugduni : sumptibus Horatii Cardon, 1615. También, Operis de religione, Lugduni, lacobi Cardon, 1632; SÁNCHEZ, T., Operis moralis praecepta decalogi..., lib. 2, cap. 42, conclus. 7, nํ 37, Lugduni, Sumptibus Laurentii Anisson, 1669; CENEDO, P. J., Practicae quaestiones canonicae et ciuiles tam vtriusq. Iuris quam sacrarum literarum studiosis vtilissimae..., Caesaragustae, apud loannem à Lanaja et Quartanet..., 1614, q. 19, no 4; DE LA TORRE, R. (O.P.), De partibus potentialibus iustitiae in secundam secundae $D$. Thomae à quaestione LXXX usque ad quaestionem CXXIII: commentaria in tres tomos diuisa: tomus primus: de religione et eius actibus, Salmanticae, apud Franciscum de Cea Tesa, 1611; DE ARAGÓN, P. (O.E.S.A.), In Secundam secundae E. Thomae... Comentaria de iusticia et iure... Venteéis: apud minimam Societatem, 1608 (también hay edición de Salamanca, 1584; SALÓN, M. B. (O.S.A.): Commentariorum in disputationem de iustitia quam habet $D$. Tho secunda sectione secundae partis sauae Summae Theologicae... / authore F. Michaele Bartholomeo Salon valentino augustiniano, Valentia, 1591. 
tableció claramente la postura oficial, afirmando que la Iglesia, en ningún caso, ejercía jurisdicción sobre los no bautizados:

"Quia Ecclesia in neminen iuditum exercet, qui non prius in ipsam per Baptismi lanuam fuerit ingressus, secundùm illud Apost. Corint. 5. Quid enim mide ijs, quiforis sunt iudicare» ${ }^{23}$.

Este sería un primer punto de crítica al que se aludiría constantemente en el siglo XVII, como hizo Francisco de Toledo en su Instrucción de sacerdotes:

«El que puede ser descomulgado, es persona determinada, bautizada, viva, inferior, subdita. Dizese persona, porque assi hombre como muger, puede ser descomulgado: pero no las aues, ni las langostas, ni los demas animales. Porque assi como ellos no comunican con nosotros en aquellos tres bienes de que tratamos arriba; assi tampoco pueden se privados de ellos» 24 .

Siguiendo esta línea, un segundo fundamento para atacar estas actuaciones era la propia irracionalidad de los seres a los que se pretendía censurar, tal como nos explica Gaspar Navarro, quien considera, por ello, tales prácticas supersticiosas y vanas:

«Y assi concluyo, que todos los Santos Doctores conformes, y sin contradicion alguna dicen, que esta manera de echar la langosta excomulgándola, es supersticiosa; y la razon es, porque se arma pleyto, y causa contra criaturas brutas, que no tienen uso de razon, para entender las cosas que les dizen; y assi es obra de vanidad, y juntamente es pecado de blasfemia, en hazer burla y escarnio de la excomunión, que usa la Iglesia Católica, contra todos los malos hombres, contumaces, y reueldes a la obediencia que deuen a los Prelados de la Iglesia»25.

En tercer lugar, también hubo quien pensó que la heterodoxia en la utilización de la excomunión se basaba en un exclusivo problema terminológico, que asociaba, erróneamente, los exorcismos o maldiciones dirigidas a las plagas con la excomunión propiamente dicha. Así se expresó, al respecto, Bartolomé Ximénez:

«Porque la excomunión tiene dos cosas, vna es, al fiel hijo de la Iglesia, en pena de sus pecados echallo, espelello, y excluyllo de la congregación, y junta de los fieles, como miembro podrido, y tenello como a Étnico, y publicano. La otra es la copia de maldiciones, que la Iglesia publica el dia que anatemiza, y mata candelas contra los tales, ya dándolos por enemigos de la Iglesia. Porque aunque esto no es ya excomunión, es consequente a ella, y assi tambien a esto llaman impropiamente

${ }^{23}$ Concilio de Trento, sesión XIV, cap. 2, cit. en NAVARRO, G., op. cit.,, disp. XXXII, fol. 97v.

${ }^{24}$ DE TOLEDO, F., op. cit., lib. I, cap. VI, fol. 8v ; también, en DE FUENTELAPEÑA, A., op. cit., secc. $3^{\text {a }}$, subsecc. 5, instancia 11, no 694 , pp. 184-185.

25 NAVARRO, G., op. cit., disp. XXXII, fol. 98v; también, en DE QUIÑONES, J., op. cit.,, cap. III, fol. 44v-r, y en MÁRTIR DE BUENACASA, P., Motivos por los quales nos castiga Dios regularmente con la plaga de Langostas, daños que ocasionan en los Reynos que las padecen, y remedios Divinos, y humanos que se han experimentado favorables en diversas Provincias para extinguirlas, Zaragoça, 1688, p. 7. 
excomunión. Pues en este sentido de tomarse la maldición por la excomunión, el essorcismo se llama tambien impropiamente excomunión (...)»26.

Son precisamente dichas maldiciones las que, a juicio de Ximénez, fundamentaban el éxito definitivo de la excomunión:

«Dar lugar Dios a que las golondrinas, y langostas, y otros gusanos, y brutos se acabasen y consumiessen excomulgándolos, y que el arbol se secasse, no es por la fuerça y virtud de las palabras, que en rigor y propiedad son de la excomunión, sino por las siguientes a ella, que son las de la maldición en que se quiere se descubra la virtud de las maldiciones, que publica la Iglesia, y la fuerça dellas» 27 .

Por otro lado, existía un último elemento de crítica para algunos autores, fundamentado en el anterior, como era la injusticia de la propia excomunión al no tener los animales responsables de las plagas conciencia para hacer el mal, en tanto que su origen era natural. En este caso, volvemos a contar con la opinión de Gaspar Navarro, tan sólo un ejemplo de otros tantos que se ocuparon del tema:

«Tambien porque las langostas, y sabandijas, y otros animales, son cosas que se engendran en la tierra por causas naturales, y no por operaciones de Demonios. Luego las amonestaciones, y citaciones de la Iglesia, que el luez les haze, son en vano, y la sentencia de excomunión contra ellas, no es justa: porque ellas no tienen culpa en lo que hazen, ni tienen voluntad para cumplir el mandamiento que les hazen, y es cosa de burla, como quien mandasse, so pena de excomunión a las aues que no graznassen, ò como quien absoluiesse a la raposa de los males que haze: porque son cosas de burla, y blasfemia en los misterios de la Santa Madre Iglesia»28.

A pesar de todo el conjunto de críticas que los autores del XVII lanzaron contra las excomuniones y los procesos judiciales, la mayoría de ellos también reconocían, a veces de forma implícita, a veces explícitamente, algunos éxitos conseguidos por estos actos en la lucha contra las plagas. Ahí estaban, indefectiblemente, los testimonios aquí comentados, aparte de otros éxitos en otros campos al margen de las plagas ${ }^{29}$.

26 XIMÉNEZ PATÓN, B., Discurso de la Langosta, que en tiempo presente aflige, y para el venidero amenaza, Con licencia en Baeça por Pedro de la Cuesta, Año de 1619, cap. 2, fols. 133r-v.

27 Idem., cap. 2, fol. 133v.

28 NAVARRO, G., op. cit., fol. 98v. Pedro Mártir hablará en esta polémica sobre la langosta en términos parecidos:

«y siendo producidas de la naturaleza, es injusta la excomunión, que se les impone; pues no siendo capazes de ella, (como se ha dicho) ni mortal, ni venialmente pecan. Y es blasfemia tener en tan poco las Censuras de la Iglesia, y reirse de ellas; como si debaxo de excomunión se mandasse â los perros, que no ladrasen, y â los lobos, que no aullasen».

(MÁRTIR DE BUENACASA, P., op. cit., p. 7; también, en DE QUIÑONES, J., op. cit., fol. 40v).

29 Gaspar Navarro alude a varios sucesos relacionados con la excomuniones. Primero, un hurto de un breviario en una iglesia francesa, el cual fue escondido en un árbol. Ante ello, el dueño del libro logró que se excomulgara al ladrón, fuese quien fuese, y, secándose el árbol citado, los vecinos de los 
En este sentido, hubo dos opiniones al respecto, no incompatibles, que pretendían explicar esos supuestos éxitos. Una opinión subrayaba el papel de Dios, que queriendo hacer ver su poder, su dominio del mundo, permitía el éxito de esos actos, obrando un milagro atribuible exclusivamente a Él y a nadie más. Es así como plantea la cuestión Juan de Quiñones en dos párrafos de su obra sobre la langosta:

"Casos han sucedido extraordinarios, en que las excomuniones han sido de tanta eficacia, que aun en los irracionales han hecho admirables efectos: pero esto ha sido por particular permission de Nuestro Señor (...)»30.

«Mas no hemos de entender que esto fue, porque los animales tuuiessen entendimiento, prouidencia y razon para sentir la excomunión, sino porque Nuestro Señor quiso mostrar sus marauillas: que cierto es que los animales irracionales no alcançan entendimiento, ni uso de razon, ni persona alguna lo puede assi afirmar, ni sentir $(\ldots){ }^{31}$.

Había, a pesar de todo, otra opinión, claramente mayoritaria, que atribuía los desenlaces felices de excomuniones y procesos a la acción del demonio. Partiendo de la base de que éste, a pesar de haber sido despojado de la gracia y de algunos dones sobrenaturales después de ser expulsado del cielo, seguía poseyendo un dominio superior sobre las cosas corporales, se admitía que mantenía potencialidad para obrar casos aparentemente milagrosos que se activaba en ocasión de excomuniones y procesos judiciales, como nos comenta Gaspar Navarro:

«(...) el auyentarse las langostas por aquellas quatro sentencias de excomunión, y el salirse los ratones, que el Obispo hizo excomulgándolos, todo fue por secreta operación del Demonio, y en estos casos obra el Demonio, matándolos, y hechizándolos, y esto no se siguió por fuerça, y virtud de la excomunión, sino por la potestad del Demonio»32.

Este poder se concretaba, unas veces, en el conocimiento de las virtudes ocultas de la naturaleza, que se unía a la ignorancia e incultura de la gente para provocar esos éxitos, tal y como afirma Benito R. Noydens:

«Y no importa decir, que se han visto efectos admirables por medio destos conjuros [se refiere a las excomuniones y procesos judiciales]; porque el demonio viendo la superstición, y desuario desta gente oculta, y secretamente con remedios nat-

\footnotetext{
alrededores se dieron cuenta, miraron dentro, y lo encontraron. Tras ello, volvió a reverdecer el árbol. En segundo lugar, otro hurto, también de un breviario, esta vez en la iglesia de la Magdalena, en Valladolid, escondiéndolo el ladrón en el interior de un olmo, ocurriendo exactamente igual que en el caso anterior. Y finalmente, otro caso, en el que ante la burla que una serie de personas hacían de las excomuniones y sus efectos ante el Padre Gonzalo de Aramonte, en Zaragoza, éste, para convencerlos de su auténtico poder, volvió primero negros unos panes, para después cambiarles el color a blanco (NAVARRO, G., op. cit., disp. XXXII, fols. 97r-98r).

30 DE QUIÑONES, J., op. cit., fol. 44r.

31 Idem, fol. 46v.

32 NAVARRO, G., op. cit., 96 r.
} 
urales haze huir la langosta; pues como tan gran filosofo conoce la virtud de las causas, y aplicando actiua passiuis, las haze producir sus efectos» ${ }^{33}$.

Pero junto a esta potestad del diablo, los autores ven otra igualmente demoníaca, como es el movimiento local, mediante el cual puede trasladar las plagas de lugar, al igual que las tempestades, los rayos, el granizo, etc. Juan de Quiñones es el que vuelve a dejar la cita más precisa:

"Y no importa que algunas vezes, o muchas obedecen la sentencia de excomunión, y dexan de hazer daño, porque esto no prouiene por virtud de la sentencia, sino de la potestad del demonio, que quita y aparta estos animales nociuos y dañosos [las langostas], y los mueue y passa de un lugar a otro (...) y esto lo haze, porque como es tan astuto y sagaz, a lo falso da apariencia de verdadero; a lo fingido de cierto; a lo inconstante de constante» ${ }^{34}$.

En todo caso, tanto en ésta como en otras operaciones demoníacas, siempre se debía contar, a juicio de todos los autores, con el permiso divino, sin el cual, simplemente, el demonio nada podía obrar.

Frente a la visión elitista del tema, expuesta hasta aquí, se hallaba la popular, que agrupaba a grandes sectores de la población, en los que se incluía buena parte de los eclesiásticos, especialmente el medio y bajo clero, imbuidos, claramente, de la mentalidad de las clases populares. Para ellas, la resolución efectiva de los problemas que afectaban a la vida cotidiana estaba por encima de cualquier tipo de precepto o moral. Por ello, con las excomuniones y los procesos judiciales nos encontramos con el carácter esencialmente instrumental que para aquellas gentes tenía la religión. Y al margen del uso real de estos actos, los que los llevaron a cabo, y los que acudieron a verlos, creían firmemente en su virtud, o eficacia, al margen de posibles estafadores.

En este punto, cabe señalar que existieron individuos foráneos que venían a realizar esos ritos, a los que se tenía, muchas veces, por superiores respecto a los locales. Este es el caso que nos cuenta, ciertamente indignado, Bartolomé Ximénez, para quien algunos tratados de siglos pasados tuvieron gran influencia en este tipo de creencias:

«Algunas vezes á auido entre los Eclesiásticos, vnos fauoreciendo el modo de conjurar destos que viene asalariados de afuera, con nombre de que tiene virtud, y eficacia particular, y el vulgo les fauorece, porque hazen conato, y eficacia (al parecer) mayor que los de la tierra (...). Particularmente an hecho aplauso en los actos de juridicion, que contra la langosta administran, y contra los espiritus diabólicos, que se presume son ministros desta plaga. Y no an faltado Eclesiásticos, que con el vulgo án favorecido esta opinión, fundados acaso en lo que se lee en el Malleo Malificarum: y en el Formicario de luan Nider (...)»35.

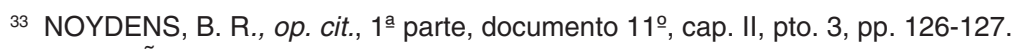

${ }^{34}$ DE QUIÑONES, J., op. cit., fol. 41r.

35 XIMÉNEZ PATÓN, B., op. cit., fols. 131v-132r. 
Sin embargo, junto a los foráneos, intervinieron, naturalmente los locales. Dentro del clero, hubo tanto regulares como seculares; y al margen de la Iglesia, hubo representantes de otros colectivos sociales, como abogados, fiscales y gente del común, que intervinieron en diversas fases de esas excomuniones y procesos. Es evidente que contra todos esos ejecutores, los intelectuales de la época cargaron violentamente, acusándoles de supersticiosos y heréticos. Pero mientras a los ajenos a la Iglesia se les podía atacar en algunos casos por mera simpleza o ignorancia en cuestiones religiosas, a los eclesiásticos se les dio el trato de ofensores de la doctrina católica. Por ello, algunos creían que era esencial aplicarles la acción disciplinaria de sus superiores jerárquicos, como era el caso de Martín de Castañega, autor de una obra antisupersticiosa en el siglo XVI, pero que, sin duda, en este caso, como en otros muchos, podía representar el sentir de los autores de la centuria siguiente:

«Mas el eclesiástico que se pone por juez en tal proceso [contra plagas] y ordena tal sentencia y fulmina tales censuras no se puede escusar de la culpa grauissima que en ello comete porque por razon de su estado i officio es obligado a saber como tal processo no es catolico y que es grande ofensa de Dios i injuria de la santa madre iglesia (...). Por lo qual los semejantes en especial los ecclesiasticos que en estas cosas se entremeten merecen ser muy reziamente castigados por sus obispos y prelados» 36 .

Para otros autores, finalmente, debía intervenir en este asunto, fueran cuales fueran las consecuencias, el verdadero garante de la ortodoxia en España, ya que era fundamental la extirpación de esa lamentable superstición. Así lo entendía Noydens:

«Ser ceremonias supersticiosas [las excomuniones y procesos], que introduce el demonio para engañarnos (...) y basta que al Santo Oficio de la Inquisición aya proueido el usar de semejante processo, con lo qual se quita toda question ${ }^{37}$.

En este sentido, desconocemos el momento concreto en que, supuestamente, el Santo Oficio integra este tipo de causas como delitos, aunque no hemos hallado rastro alguno de algún proceso de esta clase, lo que no quiere decir que no los hubiera.

Vistos todos estos argumentos, pasemos a analizar los procesos de los que hemos tenido noticia en el siglo XVII, destacando, naturalmente, el archifamoso de Párraces.

${ }^{36}$ DE CASTAÑEGA, M., Tratado muy sotil y bien fundado de las supersticiones / y hechicerías / y vanos conjuros / e ilusiones: y otras cosas al caso tocantes / y de la posibilidad i remedio dellas, Logroño, 1529, fol. 38v.

37 NOYDENS, B. R., op. cit., p. 126. 


\section{EL PROCESO DE PÁRRACES}

El interés de este proceso proviene, no de sus líneas generales, que repiten lo hasta aquí mencionado en otras actuaciones llevadas a cabo con anterioridad, sino de haber sido conservado íntegramente ${ }^{38}$, lo que supone un viaje a un microcosmos tan alejado de nosotros a todos los niveles como el agro castellano del siglo XVII. A partir del pleito podemos ver perfectamente la manera de responder de unas poblaciones ante una calamidad natural como era una plaga de langosta; $y$ sorprendernos, cuando menos, de que algunos autores actuales entiendan como superstición e ignorancia lo que no era más que una de las contadas fórmulas que el hombre de entonces tenía para hacer frente a la naturaleza.

De este proceso, nos interesarán, esencialmente, los integrantes del tribunal y los argumentos con que las partes defendieron sus posiciones, lo cual nos dará un retrato de lo que era la opinión de gran parte del clero ante determinadas realidades, así como algunas de las inquietudes y ansiedades de las gentes de aquel tiempo.

Para centrar la temática, diremos que el proceso en cuestión se desarrolló entre los días 11 y 15 de mayo de 1650, en la abadía de Santa María de Párraces, situada en la actual provincia de Segovia, entre las localidades de Segovia, Martín-Muñoz, Villacastín y El Espinar y que ejercía su jurisdicción sobre doce pueblos y aldeas de la comarca ${ }^{39}$. Todos estos lugares, por aquellas fechas, se hallaban postrados ante el cuarto año consecutivo de invasión de una terrible plaga de langosta.

Al llegar la langosta ese año de 1650, los lugareños habían recurrido primero a los remedios directos acostumbrados en esas circunstancias, como era salir hombres, mujeres y niños a coger langostas, para enterrarlas en grandes hoyos y quemarlas en hogueras. Sin embargo, al no ser suficientes estas medidas, se decidieron a utilizar también diversos medios espirituales. Solamente al fallar éstos, se decidieron a poner en práctica el último instrumento con el que contaban aquellas poblaciones para situaciones de calamidad ${ }^{40}$.

En el pleito, como en otros de este tipo, existirá un querellante, que presentará su demanda ante un juez, quien la admite, nombrando, a su vez, abogado defensor o procurador, y notario, para levantar acta de las actuaciones. Todo el proceso va a demostrar la importancia tanto del derecho como de la ortodoxia en la Castilla de la época.

38 ZARCO CUEVAS, J., op. cit. El manuscrito original se conserva en el monasterio de El Escorial, J. I. 8, pp. 422-478. Para el proceso, también ver TOMÁS Y VALIENTE, F., «Delincuentes y pecadores», VVAA, Sexo barroco y otras transgresiones premodernas, Madrid, Alianza Editorial, 1990, pp. 11-31.

39 Se trata de las actuales Aldeavieja, Bercial, Muño-Pedro, Marugán, Cobos, Etreros y San García; y los hoy despoblados de Chavente, Bernuy, Aldeanueva, Modua y Moñivar. Por otra parte, la abadía, con su jurisdicción, había sido anejada a San Lorenzo el Real de El Escorial por Felipe II en 1565, y el prior de este Monasterio llevó, entre otros títulos, el de abad de Santa María de Párraces, Idem, p. 5, nota I.

40 Idem, p. 6. 


\subsection{El Tribunal y las partes interesadas}

En principio, debemos aludir a la formación del tribunal, que responde a los esquemas mentales de la época. Así, los hombres allí reunidos no eran, ni mucho menos, los verdaderos integrantes de aquél, sino sólo los representantes de los seres celestiales que se invocaban. Por una parte, el juez de la causa era la Virgen María, representada por el provisor, vicario general de la abadía y juez eclesiástico, Fray Pedro de la Trinidad, quien, a su vez, actuaba en nombre de Fray Nicolás de Madrid, prior del monasterio de El Escorial. Nadie más apropiado que la Madre de Dios, en tanto que abogada perpetua de la humanidad en toda ocasión de peligro, para dictar sentencia en una ocasión como aquélla.

En segundo lugar, tenemos al querellante contra la langosta, que se convierte en fiscal del caso, y que no era otro que el trío de santos formado por San Gregorio Magno, San Gregorio Nacianceno y San Gregorio Ostiense, representados por el cura teniente del lugar de San García y promotor fiscal de la Audiencia Eclesiástica de la Abadía, Manuel Delgado ${ }^{41}$. Eran ellos precisamente tres de los bienaventurados a los que se tenía especial devoción como protectores contra las diversas plagas del campo ${ }^{42}$. Si ellos intercedían habitualmente ante el Altísimo en esas ocasiones, era lógico que cuando el más dañino de aquellos animales era denunciado por unos lugareños, ellos actuasen como auxiliadores de la población. No será, sin embargo, el caso del abogado de la langosta, un simple vecino del lugar de Cobos, Bernabé Pascual, sin mayor representación que la suya propia, lo que indica un trato privilegiado para con los acusadores en detrimento, claro está, del animal encausado.

Finalmente, nos encontramos con que el juez de la causa nombra como notario de la misma a San Antonio de Padua, principal patrón de la Abadía y de los lugares de su jurisdicción, actuando como delegado Antonio de Toledo, notario de aquella Audiencia Eclesiástica.

Además de los mencionados integrantes del tribunal, comparecerán también en el pleito, en calidad de parte acusadora ${ }^{43}$, las ánimas del purgatorio del lugar de Bercial, así como varias aldeas y pueblos de los alrededores, en concreto el propio Bercial, Cobos, Muño-Pedro, Chavente, Marugán, Etreros, San García y Bernuy de Párraces. Las ánimas estarán representadas por un vecino de la localidad, Este-

41 El instrumento legal que éste utiliza para querellarse contra la langosta es el pedimento, un documento procesal habitual dentro del «usus fori», TOMÁS Y VALIENTE, F., «Delincuentes y pecadores...», p. 24.

42 Según el estudio realizado por William A. Christian, Jr. de las Relaciones Topográficas de Felipe II (1575-1578), una suma muy importante de votos que entonces se mantenían en diferentes localidades de la antigua Castilla-La Nueva iba dirigida a los santos citados, CHRISTIAN JR, W. A., Religiosidad local en la España de Felipe II, Madrid, Nerea, 1991, p. 90.

43 Tomás y Valiente las denomina procuradores o representantes de quienes a título de coadyuvantes quieren hacer patente su interés legítimo y concurrente en la langosta, TOMÁS Y VALIENTE, F., «Delincuentes y pecadores...», p. 27. 
ban González, mientras que los pueblos, lo serán por sus santos patronos y abogados de lugar, actuando como delegados de éstos, vecinos, alcaldes y procuradores ${ }^{44}$.

\subsection{Los testimonios}

En primer lugar, contamos con el pedimento del fiscal acusador, quien lo inicia considerando perfectamente entendible y ortodoxa la petición de excomunión por parte de los lugareños, por los daños causados en los lugares y pueblos del contorno por la langosta en los últimos cuatro años:

"Que habiendo visto el daño grande que ha hecho y hace la langosta en todos los pueblos y términos de la Abadía, y las quexas que hay en todos, y las inquietudes y alborotos, los gastos para matalla y el mucho tiempo que se gasta en esto, teniendo necesidad los pueblos de acudir a otras cosas de grande necesidad, por cuya ocasión muchos días de fiesta se ocupan y trabajan en matar la dicha langosta; y [que] tambien les viene mucho a los pobres, por no tener los labradores con que socorrerlos y ayudar su necesidad (...)» ${ }^{45}$.

Además de estos males, la langosta puede provocar la emigración de algunos habitantes de la zona, así como importantes consecuencias negativas en iglesias, hospitales, ermitas, órdenes religiosas y ánimas del purgatorio, al disminuir las posibilidades económicas de la población y, consecuentemente, sus aportaciones para ofrendas y sufragios, tanto obligatorios como voluntarios. En este sentido, nos parecen fuera de lugar las afirmaciones de Francisco Tomás y Valiente, que considera que el principal cargo contra la langosta es el perjuicio provocado a las ánimas del purgatorio, cuando tal acusación aparece como una más del sumario ${ }^{46}$.

Volviendo al hilo argumental, el fiscal acepta, como no podía ser de otra manera, la justicia del azote de la plaga, que había llegado por los pecados humanos. Frente a ello, establece que es fundamental el ruego a Dios y la utilización de las armas espirituales de que dispone la Iglesia para este tipo de adversidades. Llegado a este punto, es cuando defiende la excomunión, en el caso que nos ocupa, como parte integrante de este arsenal, aduciendo varias causas. La primera, porque se han agotado todas las fórmulas existentes para ahuyentar al cruel animal, y nada se ha conseguido:

"Y siendo verdad notoria y manifiesta que en el caso presente se han hecho todas las diligencias ordinarias que tiene nuestra madre la Iglesia de conjuros, exor-

\footnotetext{
${ }^{44}$ Los patronos y abogados de las localidades fueron: Cobos, San Sebastián; Muñoz-Pedro, San Miguel; Chavente, San Lorenzo; Marugán, San Nicolás; Bercial, San Juan y San Pablo; Etreros, San Juan Bautista; San García, San Bartolomé; Bernuy de Párraces, Santa Olalla, virgen y mártir, ZARCO CUEVAS, J., op. cit., pp. 25-27.

45 Idem, p. 9.

46 TOMÁS Y VALIENTE, F., El Derecho Penal..., p. 299.
} 
cismos, bendición de los campos y mieses con agua bendita, con agua de San Gregorio, procesiones, novenas, rogativas, plegarias, exhortación al pueblo para que cada uno en particular suplique y encomiende a Dios, y haga reformación de costumbres, principalmente de los pecados públicos; todo lo qual está por Vuestra Paternidad mandado, y se ha executado en todos los lugares de la Abadía, y con todo eso no cesa la Langosta (...) $)^{47}$.

En segundo lugar, defiende su ortodoxia, en dos sentidos: uno, porque es un medio ya utilizado por las autoridades eclesiásticas en otras épocas; y dos, y es lo más importante, porque iguala o pone en relación la excomunión con los conjuros, práctica mayoritariamente aceptada:

«(...) y no por esto [el pleito] confieso ni es mi intento confesar que las dichas Langostas por sí propias son capaces de excomunión, sino que pido que las palabras que contra ellas se pronunciaren de excomunión sean y sirvan como conjuro fuerte y deprecación a la Divina Majestad para que cesen de hacer daño, como ha sucedido en otras ocasiones que las ha descomulgado; no apartandome en esto que pido un punto de lo que tiene y enseña la Santa Madre Iglesia» ${ }^{4}$.

Así pues, el fiscal, sabedor de la opinión mayoritaria de la jerarquía y la doctrina católica, trata, de manera muy sutil, de hacer pasar como ortodoxa una práctica que, como mínimo, suscitaba sus dudas. De este crucial punto vamos a ver también que se ocupará la siguiente figura de la que tratamos, el vicario del convento, juez de la causa, que era, en definitiva, el responsable de la apertura del juicio.

El juez del proceso va a repetir punto por punto las afirmaciones lanzadas por el fiscal para admitir la querella. Así, va a dedicar varias páginas a tratar de la idoneidad del proceso en ciernes, mostrando un gran cuidado, esmero y detallismo en sus argumentos. En las palabras del juez late el temor de ser acusado de herejía. No en balde, el animismo había sido condenado en el IV Concilio de Letrán (1215), y las explicaciones del juez sobre cómo y por qué cabe la excomunión tratan de evitar una posible acusación por esta causa ${ }^{49}$ En primer lugar, y antes de fundamentar su razonamiento, ya alude a la estricta ortodoxia del pleito, lo que induce a pensar en las grandes dudas que tenía al respecto:

«nos pareció aquí al principio hacer, como de hecho hacemos, protesta de que nuestra intención no es ir en cosa alguna contra lo que tiene, guarda y enseña Nuestra Madre la Iglesia, ni contra lo que enseñan los Sacros Cánones, y la Sagrada Teología, ni contra lo que han dicho los hombres doctos y píos; y todo lo que pareciere que desdice o se aparta de semejante sentir, desde luego lo damos por no dicho, ni para cosa alguna que sea contra la voluntad de Dios Nuestro Señor tenga efecto alguno» ${ }^{50}$.

47 ZARCO CUEVAS, J., op. cit., p. 10.

48 Idem, p. 11.

49 TOMÁS Y VALIENTE, F., «Delincuentes y pecadores...», pp. 25-26.

50 ZARCO CUEVAS, J., op. cit., p. 14. 
En segundo lugar, y basándose en la doctrina de Santo Tomás, afirma que la excomunión, siempre que sea indirecte, secundario et quasi ex consequenti, puede dirigirse también a las plagas, en tanto que posible elemento distorsionador del bienestar humano:

«(...) puede tocar y mirar la excomunión a todas las cosas del hombre, así animales, como cosas inanimadas, en cuanto son de daño o de provecho para el hombre, como se puede maldecir o bendecir ${ }^{51}$.

Esto la diferencia, claramente, de otro tipo de excomunión, que considera - secundum se - que es la dirigida al propio animal, la cual ve vana y supersticiosa, al no tener la alimaña capacidad de raciocinio, ni ser capaz de culpa.

En tercer lugar, al igualarse la excomunión a una forma de conjuro fuerte como hemos visto, se le aplican las fórmulas que la Iglesia entiende como ortodoxas a la hora de conjurar:

«En la tal excomunión, cuando las palabras de ella se dirigen a las mismas Langostas, no hay intención de dirigirlas como si ellas hubiesen de obedecer apartando el mal, sino que verdaderamente se dirige la dicha excomunión al que las mueue. Si es el demonio, se entienden por modo execratorio y compulsorio; si es Dios (...), se entienden por modo deprecatorio, pidiendo aparte aquel castigo, y en tal caso a las dichas Langostas les toca también, y les alcanza alguna fuerza o efecto de la excomunión (...)»"52.

A pesar de todo, el autor desea que las palabras de excomunión se entiendan principalmente por modo deprecatorio a Dios, para lo cual se invocarán santos auxiliadores y patronos de la Abadía, especialmente la Virgen María en su advocación local. Parece como si el miedo a parecer sospechoso de alguna heterodoxia le acabe inclinando a optar por una fórmula rogativa, cuando la realidad es que el exorcismo contaba con otra compulsiva.

Como cuarto elemento de apoyo a la querella, estará el fracaso de las diferentes medidas espirituales intentadas hasta ese momento, aduciendo que la doctrina católica defiende la gradación de los remedios si no permiten una resolución del problema:

«(...) y no es nuevo en la Iglesia, sino muy usado en ella, si una cosa no basta añadir otra, como se ve en los conjuros para las tempestades, que dice que si no cesa con lo primero, que se digan más preces y letanías; y contra los demonios, que tiene muchos conjuros, y por si los primeros no bastan, que se acuda con los otros» ${ }^{53}$.

51 Ibidem. «Esta es doctrina de Santo Tomás..., adonde preguntando si es lícito maldecir a las criaturas irracionales, responde: Que mirándolas a ellas directamente y secundum se, que es vano y ocioso maldecirlas, y por consiguiente ilícito; pero en cuanto se ordenan al hombre, pueden maldecirse... De lo cual se saca que las criaturas irracionales indirectamente, y como se ordenan al hombre, o para su bien o para su mal, se pueden maldecir o excomulgar» (Idem, pp. 14-15).

52 Idem, p. 18.

53 Idem, p. 20. 
En quinto lugar, se alude a la plena validez de la excomunión a irracionales, en tanto que siendo considerada por el juez una especie de conjuro fuerte, aunque no se hallara recogida como tal por los diferentes rituales de la Iglesia, la realidad es que tampoco estaba prohibida taxativamente, lo que le da derecho a reivindicar su uso:

"que muchas cosas se añaden por los prelados, obispos y ordinarios en las plegarias, rogativas y devociones del pueblo y de los fieles, que pueden hacerlo por no estar prohibido, acudiendo a la devoción de los fieles cuando no hay inconveniente ${ }^{54}$.

Volvemos a ver, pues, cómo fiscal y juez coinciden en presentar la excomunión como una variante de conjuro, lo cual veían, sin duda, como la forma más válida para defender sus posiciones ante la jerarquía y la doctrina.

Pero es que, incluso, el juez entiende que, aunque estuviera prohibida la excomunión concretamente, tampoco afectaría ello al pleito, porque esa prohibición se refiere a la excomunión secundum se y no a la indirecte, secundario et quasi ex consequenti.

Finalmente, se alude concretamente al proceso judicial en sí, ya que esas langostas podrían, en principio, excomulgarse por los medios ordinarios que tiene la Iglesia. A esta pregunta crucial, el juez contesta con dos fundamentos. El primero, el número de casos que en el pasado se han dado, y que han sido ejecutados por eclesiásticos píos y doctos, como hasta aquí se ha probado ${ }^{55}$.

En segundo lugar, existe una causa que tiene que ver con el carácter deprecatorio y compulsivo que, como hemos visto, daba el juez a la excomunión que analizamos. Así, el ruego a Dios lo justifica en que el proceso judicial pondría virtud y fuerza contra las langostas o cualquier espíritu que las moviera; pero también en que la excepcionalidad de este tipo de actuaciones - reconoce haber sido utilizadas poco-, por la necesidad que la informaba, fuera entendida por Dios como un recurso a la desesperada, ante el que brindaría su ayuda:

54 Ibidem. Al respecto, hay que señalar que Feijóo, décadas después, también habló sobre la diferencia entre exorcismos aprobados y meramente permitidos, cit. en DOMÍNGUEZ ORTIZ, A., op. cit., p. 191.

55 El juez alude concretamente a cuatro excomuniones realizadas por obispos en el pasado y concluidas con éxito, dos de las cuales ya fueron mencionadas en la nota 17: contra las langostas en Ávila; contra el mismo animal en Valladolid; contra los ratones en Osma; y contra las golondrinas en Córdoba, ZARCO CUEVAS, J., op. cit., pp. 21-22. Según Tomás y Valiente, la alusión por parte del juez a estos éxitos anteriores en el tiempo suena a moderno empirismo:

«En Avila, en Valladolid, en Osma, en Córdoba, excomuniones de este género han tenido éxito frente a devoradoras langostas, legiones de ratones o contra oscuras y estivales golondrinas. Probemos también nosotros: nos ampara la teología, nos protegen autorizados precedentes, y, finalmente, nuestro incipiente racionalismo se siente alentado por el éxito ajeno. Adelante. Siga el proceso. Corramos el riesgo de que verdades y creencias teológicas invencibles en el marco de la fe, sean confrontadas con la experiencia».

(TOMÁS Y VALIENTE, F., «Delincuentes y pecadores...», p. 26). 
«Lo segundo, pretendemos que viendo Dios Nuestro Señor que su Iglesia hace tales demostraciones, tan grandes y extraordinarias con tanta solemnidad y aparato, cosa que suele usar pocas veces, si no es en casos muy apretados y de grande importancia para los fieles, se mueva eficazmente a socorrer semejante necesidad, pues mira en su Iglesia demostraciones tan grandes»56.

Mucho más clara queda, sin embargo, la variante compulsiva del pleito, pues se trata, ni más ni menos, que tratar al demonio como a un delincuente común, sobre el que tiene competencia la jurisdicción eclesiástica, en tanto que elemento dañoso contra el hombre, repitiéndose el esquema presentado para justificar la excomunión:

«Por lo mismo la Iglesia le quiere tratar sujetándole a su imperio; y este dominio sobre él le viene por esta parte en cuanto hace daño al hombre y a sus cosas, y así aprieta superiormente a este tribunal al demonio, tratándole como reo, sujetándole, mandándole y sentenciándole según lo alegado y probado con sentencia de excomunión, no sólo como superior a súbdito o inferior, como hace en los demás conjuros, sino como juez a reo, que es lo que más teme (...) ${ }^{57}$.

En tercer lugar, nos encontramos con el procurador de la langosta. Su exposición —-bastante más corta que la del fiscal- se centra en dos cuestiones. La primera, muy en la línea de la época, era que Dios podía ser la causa del mal que se juzga, con lo que sería nefasto no aceptarlo y combatirlo de este modo. Y la segunda, mucho más interesante, es una defensa a ultranza del papel de la langosta en el orden natural del cosmos, tal y como lo diseñó Dios y del que el animal no se separa en ningún momento, a pesar de las desastrosas consecuencias de su actividad:

«(...) estos animales y Langostas son animales sin uso de razón, hechas y criadas por sola la virtud de Dios, para los fines que El sabe, y por su mandado y orden viven y se conservan y comen lo que su natural les dicta y propone, y así han comido de los panes porque es su mantenimiento propio, en lo cual no tienen ellas culpa alguna»58.

Así pues, la irracionalidad del animal, los objetivos inescrutables de su existencia y, por ende, de su acción devastadora, así como la completa falta de voluntad en hacer daño, son elementos que se utilizan por el abogado para pedir justicia en el pleito, pero, en ningún caso, para desautorizar al tribunal o al proceso en sí.

A continuación, entran en escena las ánimas del purgatorio del lugar de Bercial, elemento que era esencial en la época en dos sentidos. Por una parte, se trataba de las almas de los propios difuntos, que intentaban purgar las penas temporales para lograr el cielo. Por otra, una vez instaladas en la corte celestial, se

56 ZARCO CUEVAS, J., op. cit., p. 24.

57 Idem, p. 23.

58 Idem, p. 24. 
convertían en válidos intercesores ante Dios en cualquier ocasión de peligro que se cerniera sobre los hombres. En ambos casos, pues, los sufragios dirigidos a las ánimas se hacían imprescindibles para el cumplimiento de sus aspiraciones y obligaciones $^{59}$, por lo que una disminución de la cosecha, provocada por cualquier calamidad, como era aquella plaga repetida durante varios años, daba al traste con esas aspiraciones.

La honra de los muertos, y el papel medianero de las ánimas, se hallaban, así pues, en peligro. Desde esta óptica, nada más lógico que su comparecencia en aquel pleito para fundamentar sus alegaciones contra la langosta en el sentido indicado:

«Las Animas del Purgatorio, y Esteban González, vecino de Bercial, como Procurador de las dichas Animas, parezco ante V. P. [el juez de la causa] (...) y pido, que por cuanto las Animas del Purgatorio reciben mucho detrimento por razón de la falta de frutos con que se cumplen las memorias, así voluntarias como obligatorias, de las dichas Animas, y se defraudan las misas que los fieles suelen decir, y otros muchos bienes que se impiden por esta infernal plaga que nos aflige $(\ldots) \gg 60$.

Finalmente, son varias poblaciones que, como en el caso de las ánimas, se personan también como parte acusadora y repiten, punto por punto, todas las alegaciones realizadas al principio por el fiscal, resaltando todos los males que la plaga había traído en los últimos años, a partir de la pérdida de las cosechas de trigo, viñas y otros productos de la tierra: ruina y empeño de numerosas familias y descuido de las limosnas y obligaciones al culto religioso en general ${ }^{61}$.

\subsection{Respuestas a los pedimentos de los querellantes, turno de alegaciones y pruebas}

Establecidas así las posiciones de cada parte, se entrará en otra fase del juicio, que son las respuestas del abogado y fiscal ante las peticiones de los querellantes. El primero no variará un ápice su postura original, sobre la inocencia de la langosta como elemento dentro del orden establecido en el mundo. Sí interesará, y mucho, la respuesta del fiscal, que demostrará la idea, imperante en la época, sobre el orden natural del cosmos, en el que el animal citado no cumplía su papel.

59 Los sufragios por los difuntos suponen la constitución de vastas solidaridades entre vivos y muertos: existencia de instituciones de vinculación que financien los sufragios - testamentos- o hagan de ellos una práctica obligatoria - cofradías-; reforzamiento de cohesión de comunidades —familias carnales, religiosas, de confraternidad-; y creación de un instrumento de poder para la Iglesia, que afirma su derecho sobre las almas del purgatorio como miembros de la Iglesia militante, así como consigue un provecho financiero -indulgencias-, LE GOFF, J., El nacimiento del Purgatorio, Madrid, Taurus, 1981, p. 22.

60 Idem, p. 25.

61 Idem, pp. 25-27. 
Frente a la opinión del abogado, que considera la actuación de la alimaña como conforme a la voluntad divina, el acusador referirá que el sustento de la langosta sólo debe ser «la yerba de los caminos y campos baldíos y otras partes que no sirven a los hombres». Además, en el caso de faltar sustento, debe tenerlo prioritariamente el hombre por una causa elemental:

«(...) pues ellas [las langostas] son animales sin razón, y los hombres son hechos a la imagen y semejanza de Dios, a los cuales dio su Diuina Majestad... por sustento particular y suyo el trigo; y dio a cada animal su propio sustento, y los panes no es pasto propio y legítimo de las Langostas (...), sino es en caso que sobre a los hombres» ${ }^{62}$.

Por tanto, por encima de las funciones propias de cada ser, vemos que el fiscal prima el orden en la escala del cosmos, y así, después de Dios y toda la corte celestial, se hallaba el hombre, y después el resto de la naturaleza, clasificación que debía primar en una situación de peligro como aquélla. Si aceptamos los parámetros mentales de la época, también este fundamento parece bastante lógico, tan lógico como el del procurador.

En segundo lugar, nos encontramos en los últimos turnos de alegaciones del abogado y fiscal con otra polémica, como es la elucidación de quién y por qué ha traído la plaga a aquella comarca, reproduciéndose nuevamente las opiniones al respecto de los intelectuales de la época. A la alegación del abogado, que defendía la posible intervención divina, responde contundentemente el fiscal con dos argumentos. El primero es que es bastante probable que el causante de todo sea el demonio:

«(...) porque el odio mortal que tiene al género humano le mueve a hacer a los hombres todo el daño que puede, y se le permite, como se ve cada dia en las tempestades que mueve, y en otros muchos daños que no cesa de hacer a los hombres».

Ante ello, se tienen los "conjuros eclesiásticos ordinarios", pero como este método se ha intentado ya, y ha fallado, se recurre a la excomunión - «conjuro eclesiástico extraordinario", para el fiscal—, ya que ha sido un instrumento utilizado en otras ocasiones.

Y el segundo, es que, si resultara al final que no es el demonio, sino Dios, debido a los pecados humanos, también sería lícito el uso de la excomunión, porque en situaciones de emergencia, el hombre debe rogarle mediante todas las fórmulas posibles, siendo lo fundamental fiarlo todo a su excelsa misericordia ${ }^{63}$.

Frente a este alegato, el procurador responderá, igualmente, de dos maneras, aceptando la hipótesis planteada por el fiscal. En primer lugar, si como él

62 Idem, p. 29.

63 Idem, pp. 29-30. 
cree, es Dios el fundamento de la plaga, ésta puede buscar dos objetivos, a cada cual más lícito. El primero, sería castigar las faltas humanas, como ya hemos expuesto más atrás. Pero podría haber un segundo motivo, que consistiría en hacer que el hombre ahondara en la virtud a través de una calamidad, por lo que la plaga no sería, en este caso, tan nefasta como parece:

«De manera que semejante plaga, aunque no es en provecho de los cuerpos, puede ser en provecho de las almas; porque así afligidos se reconocen y humillan; y se ha de mirar más por el provecho del alma que por el del cuerpo ${ }^{64}$.

En segundo lugar, si fuera diabólica la causa del mal, el Maligno siempre actuaría con permiso divino, con lo que se seguiría demostrando que la langosta era movida por otro y no tenía voluntad alguna de dañar. Pero, además, el arma final contra esta calamidad debía ser el exorcismo, y no la excomunión, "que esta arma de la Iglesia ha de ser para casos de otra calidad y no para ésta». Sin estridencias, a base de datos múltiples, el procurador responde a todos y cada uno de los fundamentos esgrimidos por el fiscal.

Finalmente, nos hallamos en la fase de pruebas, en la que sólo vamos a encontrar cuestiones ya repetidas por parte de los diferentes testigos que el fiscal y el procurador presentan a la Audiencia, para ratificar sus propias opiniones. Sobre los testigos, los del fiscal fueron ocho vecinos, que representaban a cada una de las poblaciones querellantes, y los del procurador, un asistente y dos criados del convento.

Aunque el juez había dictado nueve días para los testimonios de cada uno, el proceso se aceleró, y tres días después de comenzar — la presentación de la querella está fechada a 11 de mayo-, se dicta sentencia el sábado, 14.

\subsection{La sentencia}

En esta última secuencia del juicio, se vuelve a ver, claramente, la importancia del derecho y la ortodoxia, pero también la acumulación de elementos para conseguir el final de la plaga. Así, en primer lugar, el juez va a pronunciar cuatro sentencias. Las tres primeras -interlocutoria, de revisión y definitiva - se dictan el 14 de mayo, notificándose las dos primeras a las partes interesadas por si deseaban realizar un último turno de alegaciones, y comunicando a aquéllas la realización de la sentencia definitiva. La publicación de las tres sentencias, junto con el auto de culpa y cargo contra las langostas, se lleva a cabo al día siguiente, domingo, fiesta de guardar por antonomasia, además de 15 de mayo, fiesta de San Isidro Labrador, personaje celestial muy ligado a la protección de la agricultura. Además, la publicación de la sentencia se lleva a cabo en el cementerio de la iglesia parro-

64 Idem, p. 31. 
quial de Santa María de Párraces, en presencia de la inmensa mayoría de los vecinos de aquella comarca asolada, que, previamente a oírla, habían acudido, por mandato del propio vicario, a una procesión general para rogar a Dios por el final de la plaga, y por agua para sus cosechas.

Se observa, pues, que en el ritual ningún elemento es casual ni está de sobra, sino que todos son complementarios y ayudan a conseguir el objetivo deseado. Tanto la fecha, como el público presente y la procesión que se realiza, responden a la consecución del mismo fin.

Por otro lado, en la sentencia final se declara absuelto al promotor fiscal que se querelló contra la langosta al fallar a su favor, mientras que del procurador de la misma se dice que no probó su argumentación, pero el que es declarado culpable es el animal, «que fue la parte que pretendió defender, por lo qual se le acumulan todas las penas del derecho, que da a los rebeldes y contumaces».

Además, la citada sentencia será dictada por el vicario general tan sólo en calidad de representante del auténtico juez celestial:

«Nos, Santa María, Madre de Dios y Señora del cielo y tierra, Juez que somos nombrada en esta causa, y en nuestro nombre, y haciendo nuestras veces con nuestro mismo poder y autoridad: Nos, fray Pedro de la Trinidad, Provisor y Vicario general de Santa María de Párraces y Lugares de la Abadía».

Sobre el contenido en sí del fallo, hay que señalar que se hacen varios cargos a la langosta, entre los que destacan los daños causados por ella sobre campos y frutos, $y$, consecuentemente, los perjuicios ocasionados a hombres, ganados, pobres, religiosos, ánimas del purgatorio, etc., así como el gasto en las actuaciones llevadas a cabo para eliminarla:

«Tambien se les hace cargo de los daños que resultan así a los eclesiásticos como a los seglares, por las inquietudes que causan a todos, y el tiempo que gastan los unos en matarlas y los otros en conjurarlas, no haciendo efecto su trabajo»65.

Se iguala, pues, la contumacia ante el arma espiritual con la resistencia ante la

humana, demostrándose que a la Iglesia de entonces le preocupaba tanto la lucha divina como la humana ante las calamidades naturales.

Todo ello viene a ratificar, más o menos, la querella del fiscal. En este sentido, se condena a la langosta a abandonar la zona en un plazo de tres días, so pena de excomunión mayor. Tomás y Valiente ha querido ver en este fallo un interés meramente local por deshacerse de la calamidad, sin importar si ésta se desplazaba a otro lugar contiguo ${ }^{66}$. A este respecto, debemos hacer dos aclaraciones. La

65 Idem, p. 37.

66 En su obra afirma lo siguiente: 
primera, que no es verdad esta aseveración, y para ello nos servimos del texto de la sentencia del 14 de mayo:

«FALLAMOS que debemos condenar y condenamos a la dicha Langosta, así a la presente como a la venidera, a que sea desterrada de todos los términos y lugares desta Abadía, y de cualquiera parte que pueda hacer daño, y no vuelva jamás a los dichos términos y la damos de término tres días naturales (...) so pena de excomunión mayor latae sententiae trina canonica monitione en derecho praemissa».

La segunda aclaración es que, aunque así se hubiera obrado, las poblaciones tenían motivos para justificarlo. Si las localidades apenas podían mirar por ellas mismas a la hora de su desarrollo, o de hacer frente a los dictados de la naturaleza, ¿por qué iban a preocuparse por los intereses de la comarca de al lado?

Para completar el proceso, conviene añadir que, tras las sentencias del 14 de mayo - publicadas el 15-, hubo otra el día 21, ya que el plazo dado —-tres días - había vencido y la plaga continuaba. En esta cuarta sentencia — denominada declaratoria - se la excomulga definitivamente, dándole un nuevo plazo de 24 horas para abandonar el lugar, so pena de excomunión mayor para rebeldes, aunque insistiendo en que el mal que no querían para Párraces no lo deseaban para nadie:

«(...) salgan dentro de veinte y cuatro horas de los dichos términos, y no vuelvan a ellos, y vayan a los montes y lugares silvestres y baldíos adonde tendrán su mantenimiento necesario, desando el que es propio de los hombres y ganados».

Así pues, aún se mantenía el derecho al sustento de la langosta, cosa que desaparecía si se incumplía esta cuarta sentencia, pena que se unía a la de merecer su muerte, así como el ser declarada rebelde y contumaz. Incluso en este último pasaje, continúa la vigencia del derecho, en este caso, en su potestad de graduar el castigo.

Nada sabemos sobre los acontecimientos en aquel término durante las semanas siguientes. Lo único que nos comenta Julián Zarco Cuevas es que la plaga volvió nuevamente por allí en 1651 y 1709 y que, contra ella, volvió a realizarse proceso y excomunión ${ }^{67}$.

«(..) se dictó sentencia condenatoria contra las langostas, en la que se imponía la pena de destierro «de todos los lugares desta Abadía». Detalle éste muy significativo: para el juez penal eclesiástico, el cosmos y su «ordo naturalis» estaba limitado estrechamente por los lindes de su jurisdicción de campanario. Las grandes abstracciones del planteamiento se materializan en un contorno territorial muy concreto. Había que desterrar a las langosta; pero ¿de dónde? ¿Del mundo todo? No, simplemente de las tierras de la Abadía de Párraces; más allá, ique se las compusiera con las langostas el juez competente del nuevo lugar en que se cobijasen!».

(TOMÁS Y VALIENTE, F., El Derecho Penal..., pp. 299-300).

67 ZARCO CUEVAS, J., op. cit., p. 8, nota I. 


\section{OTROS PROCESOS}

Al margen de lo visto hasta aquí, contamos con otros casos en otras partes de España. Del primero de ellos, tenemos una información incompleta, a partir de la ya citada obra de Gaspar Navarro, en la que no se especifica ni el lugar ni la fecha en que acaeció, suponiéndose que pudo ocurrir en los primeros años del siglo XVII por el cálculo respecto de la fecha en que se publicó la obra que nos suministra la información. Su autor nos lo muestra así:

«Esta Disputa he movido, porque aurà mas de veynte años que vi en cierta Diocesis hazer processo, poniendo el Oficial Eclesiástico Procuradores contra la langosta, y hazer sus demandas, y respuestas, llevar lite formado. Y después de auer pasado los terminos jurídicos, proferir sentencia de excomunión contra la langosta, y vi que la gente simple, y muchos Pueblos se opusieron, haziendo parte contra ella»68.

En segundo lugar, aunque al margen de las plagas del campo, contamos con otro caso narrado por Gil González Dávila. En 1616, unos pescadores de los puertos más cercanos a la ciudad de Oviedo vinieron a querellarse ante la Audiencia eclesiástica, alegando que unos delfines les rompían las redes y les impedían, de esta manera, el trabajo y la obtención de su sustento. Ante ello, el obispo de la diócesis mandó que se diesen censuras contra los animales, nombrándose, igualmente, abogado y fiscal. En este caso, el proceso se desarrolló en el mar, yendo a bordo de un barco todos los interesados, incluyendo testigos y notario. Precisamente éste fue el encargado de leer a los delfines las censuras, para que no volviesen por esos mares, consiguiéndose un final feliz ${ }^{69}$.

Finalmente, también hallamos referencias - que no pleitos- en una obra sobre la langosta en el antiguo reino de Córdoba. Sus autores, Rafael Vázquez y Santiago Álvarez, que investigaron a fondo todas las fuentes primarias posibles, en especial la del archivo catedralicio de la capital andaluza, no hallaron, finalmente, ni un solo proceso contra la citada plaga, lo cual, según ellos, es extraño, teniendo en cuenta lo azotado que estuvo el reino por la misma ${ }^{70}$. Igualmente, nada se ha encontrado al respecto en zonas históricamente tan inundadas como Jaén, La Mancha o la Serena ${ }^{71}$,

68 NAVARRO, G., op. cit., disp. XXXII, fol. 95r. La obra en cuestión es de 1631, con lo que la resta de esos 20 años, nos llevaría, aproximadamente, a 1610.

69 GONZÁLEZ DÁVILA, G., Teatro Eclesiástico de la Santa Iglesia de Oviedo, Madrid, 1635, pp. 90-91.

70 VÁZQUEZ LESMES, R. y SANTIAGO ÁLVAREZ, C., Las plagas de langosta en Córdoba, Córdoba, Publicaciones del Monte de Piedad y Caja de Ahorros de Córdoba (Cajasur), 1993, p. 140.

71 SALIDO Y ESTRADA, A., La langosta. Compendio de todo cuanto más notable se ha escrito, sobre la plaga, naturaleza, vida e instintos de este insecto, Madrid, 1874, pp. 55-6; RIVAS MORENO, F., La plaga de langosta. Sus estragos, medios de combatirla y juicio crítico de la legislación vigente, Madrid, 1887, pp. 2-3; VÁZQUEZ LESMES, R., y SANTIAGO ÁLVAREZ, C., op. cit., p. 62; LÓPEZ CORDERO, J. A. y APONTE MARÍN, A., Un terror sobre Jaén: las plagas de langosta (siglos XVI-XX), Jaén, Ayuntamiento de Jaén, Concejalía de Cultura y Turismo, Servicio de Publicaciones, 1993, p. 281. 


\section{CONCLUSIONES}

Las excomuniones y los procesos judiciales contra seres irracionales fueron uno de tantos instrumentos espirituales utilizados por la Iglesia católica en España durante la Edad Moderna para hacer frente a las plagas del campo. A pesar de que una gran mayoría de autores vertieron feroces críticas contra dicho modo de proceder, esos mismos aceptaban su eficacia, atribuyendo el éxito, bien a Dios a través de milagros, bien al demonio mediante sus amplios poderes sobrenaturales, conservados a pesar de su caída.

En la confluencia de las opiniones manifestadas por los tratadistas que analizaron la temática en el XVII español, y de los procesos judiciales llevados a cabo durante la citada centuria — con especial relevancia, el de Párraces-, pero también en la anterior, se atisban dos opiniones radicalmente diferentes. Por una parte, se encuentran aquellas personas que justificaban el uso de dichas prácticas, como fueron los jueces y fiscales de los mencionados pleitos. A partir de los grandes y diversos daños ocasionados por las plagas en las comunidades humanas -fundamento de la utilización de excomuniones y procesos judiciales-, se desarrollan las justificaciones de su uso, que son, básicamente cinco. La primera, el fracaso de los remedios espirituales llevados a cabo previamente a excomuniones y procesos. La segunda, la utilización de dichas prácticas por la Iglesia, en otras épocas, de forma exitosa. La tercera, la consideración de excomuniones y procesos como recursos extraordinarios, en situaciones de emergencia, que contarían, por ello, con el visto bueno divino. La cuarta, la igualación entre excomunión y conjuro fuerte, lo que daría a la primera una etiqueta de ortodoxia. Y la quinta, la aceptación del orden en la escala del cosmos, por lo que la subsistencia del hombre prima sobre la del animal.

Por otra parte, se hallan aquellos autores que, juntamente con los abogados de los pleitos judiciales contra irracionales, veían a ésos y a las excomuniones como lesivas contra la ortodoxia católica y, por ello, claramente supersticiosas. Sus argumentos son, fundamentalmente, cuatro. Uno, los animales no pueden recibir excomuniones, ya que éstas solamente se dirigen a personas bautizadas. Dos, una posible causa del azote puede ser Dios, en cuyo caso hay que aceptarlo de manera resignada, ya que el fin de la calamidad es ejemplarizante en todo caso, bien sea el castigar las faltas humanas, bien el obligar al hombre a ahondar en la virtud. Tres, otro posible origen de la plaga puede ser el demonio, y en tal caso debe combatírsele mediante los exorcismos. Y cuatro, se reconoce la función propia de cada ser en el cosmos y, por tanto, el instinto y la falta de voluntad en las acciones de los animales.

Finalmente, y ante los casos analizados y las investigaciones llevadas a cabo por diversos estudiosos, hemos de pensar que las excomuniones y los procesos judiciales en España durante la Alta Edad Moderna fueron escasos. En ello pudo haber influido perfectamente el miedo a la posible heterodoxia del remedio. Sin em- 
bargo, mucho se habló entonces sobre los procesos. Desde esta óptica, la relevancia desproporcionada dada al tema por los manuales de la época respondería a lo raro del ritual, que causaría sorpresa a propios y extraños, y por ello, suscitaría comentarios de diversa índole.

A pesar de esta opinión, creemos que sólo una cuidadosa investigación de los diversos archivos civiles y eclesiásticos de las zonas geográficas más azotadas por las plagas podría acabar con la polémica. 